\title{
The effect of inoculation of the root system with Cylindrocarpon magnusianum on plant performance exposed to heavy metal salts
}

\author{
Irina Bukharina ${ }^{1 *}$ D, Nadezhda Islamova ${ }^{1}$ D \\ ${ }_{1}^{1}$ Udmurt State University, Izhevsk, Udmurt Republic, Russia. E-mail: bukharina.usu@inbox.ru; islamova.usu@ro.ru
}

ABSTRACT: The effect of inoculation with endotrophic micromycete Cylindrocarpon magnusianum on the formation of adaptive physiological and biochemical reactions in test tomato plants under the action of heavy metal salts has been studied. The experimental design included plant inoculation with a fungus culture (control population) and these fungus populations were preliminarily grown on a pentose-dextrose agar medium with the addition of heavy metal salts in different concentrations. The inoculated plants were grown on substrates without the addition of heavy metal salts (control) and with the addition of zinc, copper, lead, and chromium salts in different concentrations similar to additions in agar when growing fungus populations. In experimental plants, we determined the content of photosynthetic pigments and ascorbic acid in the leaves (spectrophotometry), nitrates in the leaves (ionometric analysis), the aerial part and root system biomass by the gravimetric method, and the degree of fungal infection development of plants via the light microscopy method of macerated and colored fragments of the plant root system. No stimulatory effect, increasing the resistance of plants to the action of heavy metal salts when plants were inoculated with a control population of the $C$. magnusianum fungus, was revealed. A positive effect was revealed during the inoculation of plants with fungal populations, previously adapted to the action of salts of chemical elements, especially chromium and lead salts, and during further plants' cultivation on substrates with the introduction of these non-biogenic chemical elements hazardous to the life of plants. The effect is associated with the stability of the pigment system, the redistribution of plant biomass, and the synthesis of the antioxidant-ascorbic acid in the leaves. Intensive development of fungal infection in plant roots was also noted. The study results indicate the most effective partnership between the $C$. magnusianum fungus and the plant root system under stressful conditions for plant life.

Key words: biochemical indicators; chromium; copper; lead; micromycetes; Solanum lycopersicum; zinc

\section{Efeito da inoculação do sistema radicular com Cylindorcarpon magnusianum na performance de plantas expostas a sais de metais pesados}

RESUMO: Foi estudado o efeito da inoculação com o micromiceto endotrófico Cylindrocarpon magnusianum na formação de reações fisiológicas e bioquímicas adaptativas em plantas de tomate sob a ação de sais de metais pesados. 0 delineamento experimental incluiu a inoculação das plantas com cultura de fungo (população controle) e essas populações de fungos foram cultivadas preliminarmente em meio de ágar pentose-dextrose com adição de sais de metais pesados em diferentes concentrações. As plantas inoculadas foram cultivadas em substratos sem adição de sais de metais pesados (controle) e com adição de sais de zinco, cobre, chumbo e cromo em diferentes concentrações semelhantes às adições em ágar no cultivo de populaçổes de fungos. Em plantas experimentais, determinamos o teor de pigmentos fotossintéticos e ácido ascórbico nas folhas (espectrofotometria), nitratos nas folhas (análise ionométrica), parte aérea e biomassa do sistema radicular pelo método gravimétrico, e o grau de desenvolvimento da infecção fúngica de plantas pelo método de microscopia de luz de fragmentos macerados e coloridos do sistema radicular da planta. Nenhum efeito estimulador, de aumento da resistência das plantas à ação de sais de metais pesados, quando as plantas foram inoculadas com uma população controle do fungo $C$. magnusianum, fó revelado. Um efeito positivo foi revelado durante a inoculação de plantas com populações de fungos previamente adaptadas à ação de sais de elementos químicos, especialmente sais de cromo e chumbo, e durante o cultivo posterior de plantas em substratos com a introdução desses elementos químicos não biogênicos perigosos para a vida das plantas. $O$ efeito está associado à estabilidade do sistema de pigmentos, à redistribuição da biomassa vegetal e à síntese do ácido ascórbico-antioxidante nas folhas. 0 desenvolvimento intensivo de infecção fúngica nas raízes das plantas também foi observado. Os resultados do estudo indicam a parceria mais eficaz entre o fungo C. magnusianum e o sistema radicular da planta sob condições estressantes para a vida da planta.

Palavras-chave: indicadores bioquímicos; cromo; cobre; chumbo; micromicetos; Solanum lycopersicum; zinco

\footnotetext{
* Irina Bukharina - E-mail: bukharina.usu@inbox.ru (Corresponding author)

Associate Editor: Mário de Andrade Lira Júnior
} 


\section{Introduction}

Currently, the scientific community has experienced an increased interest in studying the role of the consortium ties of plants with root micromycetes. Certain successes have been achieved in studying the role of endomycorrhiza and its most common form - arbuscular mycorrhiza (AM), which is typical for most modern phylogenetic groups of plants and is introduced in all biomes of the globe. It is formed by fungi belonging to the Glomeromycotina subdivision of the Mucoromycota division (Yurkov et al., 2018). However, the use of arbuscular mycorrhizal fungi (AMF) in crop production is limited, which is a consequence of their obligate symbiotrophy (Ijdo et al., 2011). In this regard, studying the role of other groups of root micromycetes of endophytes and their individual representatives in the formation of resistance mechanisms in higher plants is of particular interest. Historically, two groups of endophytes (Clavicipitaceous and Nonclavicipitaceous) have been distinguished on the basis of phylogeny and signs of life-cycle (Rodriguez et al., 2009; El-Samad et al., 2019). In general, this heterogeneous group of fungi can have a strong effect on plant communities by ensuring the resistance of plants to abiotic and biotic stress. Studies on the endophytes' role in the formation of plants' resistance to metals, including crops (Rodriguez et al., 2009; Ikram et al., 2018; Bilal et al., 2019; Dabral et al., 2019; El-Samad et al., 2019), and with regard to chemical elements that are extremely dangerous for plants (Ali et al. 2019; Bilal et al., 2020; Li et al., 2019; Sharma et al., 2019; Hou et al., 2020) are of particular interest. A number of studies are aimed at examining the possibility of using micromycetes as herbicides (Sogonov \& Velikanov, 2004; Boyette et al., 2016; Boyette et al., 2018; Meepagala et al., 2019; Sobowale, 2019).

One of the promising micromycetes is the endophyte of Cylindrocarpon magnusianum Wollenw (Amaral et al., 2009; Bukharina \& Islamova, 2016). It has been established that its metabolites can be used in the fight against nematodes (Amaral et al., 2009), thanks to its ability to grow under conditions of high oil content in the soil (Amaral et al., 2009; Bukharina \& Islamova, 2016). During a series of authors' experiments conducted with $C$. magnusianum, it was found that the culture of this fungus is able to withstand high osmotic pressure while maintaining the growth of cultural mycelium. Plus, experiments with plants inoculated with this fungus show the possibility of its use as an agent for increasing their salt tolerance (Bukharina et al., 2016).

The aim of our research is to study the effect of inoculation with the $C$. magnusianum fungus culture on the formation of adaptive plant responses to the action of heavy metal salts (HM) in the substrate (using the test culture of Solanum Lycopersicum L. tomato as an example).

\section{Materials and Methods}

The culture of $C$. magnusianum was isolated from the root system of woody plants (Acer negundo L. in good life condition), which grow for a long time in urban soils with a high content of heavy metal salts (in plantings along the highway and sanitary protection zone of Izhstal JSC, Izhevsk, Udmurtia, Russia). The fungus is cultivated on a nutrient medium outside the root system of plants. The fungus species was established by microscopy and molecular DNA (deoxyribonucleic acid) analysis in the laboratory of the Leibniz Institute for Vegetable and Ornamental Crops (Berlin) (Bukharina et al., 2016).

According to the experimental scheme, the fungus populations adapted to substrates with different concentrations of heavy metal salts (HM), $\mathrm{mg} \mathrm{l}^{-1}$ : $\mathrm{AO}$ control; $\mathrm{A} 1$ - on a substrate with $\mathrm{Zn}_{100} ; \mathrm{A} 2-\mathrm{Cu}_{50} ; \mathrm{A} 3-\mathrm{Cu}_{100}$; $\mathrm{A} 4-\mathrm{Cu}_{150} ; \mathrm{A} 5-\mathrm{Pb}_{10} ; \mathrm{A} 6-\mathrm{Pb}_{50} ; \mathrm{A} 7-\mathrm{Cr}_{2,5} ; \mathrm{A} 8-\mathrm{Cr}_{10}$ were

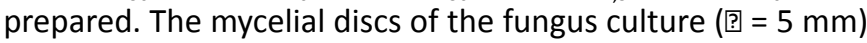
were transferred to a pentose-dextrose agar medium (PDA medium) (GVS, Italy) with added HM salts according to the calculated concentrations and were incubated for two weeks in a climatic chamber "BinderKBWF720" (Binder, Germany) at a temperature of $+25^{\circ} \mathrm{C}$.

Then, the suspension cultures of these populations were prepared (spore content - 3 million pcs $\mathrm{ml}^{-1}$; mycelium fragments - 200 pcs $\mathrm{ml}^{-1}$ ) and plants were inoculated by watering seedlings with a suspension $(25 \mathrm{ml}$ of suspension per 1 plant) during the picking period. To prepare the suspension cultures of the fungus in a sterile potato broth with dextrose (Potato Dextrose Broth [GVS, Italy]), mycelial discs of adapted fungus populations were introduced and incubated for 10 days in an ES-20/60 thermo-shaker-incubator (Biosan, Latvia), temperature $+25-27^{\circ} \mathrm{C}$, rotation $60 \mathrm{rpm}$ (patent for invention No. 2722206: method of preparation and introduction of a fungal biological product to increase plant resistance, the date of state registration in the State Register of Inventions of the Russian Federation 05.28.2020).

The experiment included the following options: 1) inoculated tomatoes (inoculation with control isolate A0) were grown on substrates with different contents of heavy metal salts, $\mathrm{mg} \mathrm{l}^{-1}$ : B0 - control - without HM; B1 - $\mathrm{Zn}_{100}$; B2 $-\mathrm{Cu}_{50} ; \mathrm{B} 3-\mathrm{Cu}_{100} ; \mathrm{B} 4-\mathrm{Cu}_{150} ; \mathrm{B} 5-\mathrm{Pb}_{10} ; \mathrm{B} 6-\mathrm{Pb}_{50} ; \mathrm{B} 7-\mathrm{Cr}_{2,5} ; \mathrm{B} 8-$ $\left.\mathrm{Cr}_{10} ; 2\right)$ tomatoes inoculated with fungi populations adapted to heavy metals (A1-A8) were grown on substrates without addition (B0) and with the addition of $\mathrm{HM}$ salts (B1-B8). Control - an initial population that is not adapted to $\mathrm{HM}$ salts (corresponds to AO in Figures 1-3) and the substrate without $\mathrm{HM}$ salts (corresponds to B0 in Figures 1-3).

The experiment was repeated four times. The substrate was a 1:2 mixture of low ash peat and sand. The plants were cultivated in containers (with a substrate weight of $300 \mathrm{~g}$ and a moisture content of $75 \%$ ) and in a climatic chamber "BinderKBWF720" under the optimal conditions of tomato culture (substrate moisture content $75 \%$, illumination 20,000 lux [16 hours a day], air temperature during daylight hours - $23^{\circ} \mathrm{C}$; at night $-19^{\circ} \mathrm{C}$ ). We used a dwarf tomato variety "Balcony Miracle." Plants were grown for three months before the onset of fruiting.

At the end of the experiment, the development of endophytic fungi in the roots was assessed by light microscopy 
using a Levenhuk D870T digital microscope, 8 Mpix, trinocular (Levenhuk, Germany) (Shtark \& Labutova, 2014). The plant resistance assessment was carried out on the basis of: the content of nitrates in the leaves - by the ionometric method (GOST 29270-95 (Gostperevod, 2010), S230-Kit conductometer) (Mettler Toledo, Germany); the biomass and percentage of dry matter in the aboveground part and root system of plants via the gravimetric method (scales HR-250 AZG) (A\&D Scales CO., LTD., The Republic of Korea), drying cabinet LF-120/300-GG1 (LOIP, Russia) (according to the GOST 28561-90 (Gostperevod, 2011); photosynthetic pigments in the leaves of the middle layer (chlorophylls $a$ and $b$, carotenoids) spectrophotometrically in acetone extracts (absorption 662, 644, and $440.5 \mathrm{~nm}$, respectively, spectrophotometer PE-5400 UF, 200.04.031, "EKROSKHIM," Russia), the concentration of pigments was calculated using Holm-Wettstein equations; vitamin C (ascorbic acid) spectrophotometrically (spectrophotometer PE-5400 UF, 200.04.031, "EKROSKHIM," Russia)

The mathematical processing of materials was carried out using the statistical package "Statistica 6.0" via descriptive statistics methods. Significant differences were established at $p<0.05$.

\section{Results and Discussion}

The analysis of the results showed (Figures 1-3) that in all variants with zinc addition the pigment content in the leaves of plants had common patterns: inoculation of plants with a control population when grown on a substrate with zinc (AOB1) did not have any effect on the content of photosynthetic pigments; inoculation of plants by adapted populations, when grown on a control substrate (A1B0), caused a significant increase in the content of chlorophylls $a$ and $b$, carotenoids, and when grown on a substrate with zinc (A1B1), in contrast, a significant decrease in the content of pigments was observed - almost twice as much. As for the other studied parameters (Table 1), inoculation of the control population when growing plants on a substrate with zinc (AOB1) led to a significant decrease in the dry matter content in the root system of plants. Inoculation with adapted populations of the fungus caused a true decrease in the top biomass of plants (when grown on a control substrate [A1B0]) and did not affect the studied parameters of plants when cultivated on a substrate with zinc (A1B1).

High rates of development of fungal infection of $C$. magnusianum in the root system of plants were noted in the control population / $\mathrm{Zn}_{100}$ variant (Table 1 ), but while using adapted populations the fungal infection was less developed, especially in the $Z \mathrm{n}_{100} / \mathrm{Zn}_{100}$ variant.

In variants with $\mathrm{Cu}_{100}$, an increase in the content of chlorophylls $a$ and $b$ was found when using adapted populations (A3B3) while, in contrast, inoculation with the control population (AOB3) led to a significant sharp decrease in the pigment contents. In variants with the maximum copper content $\mathrm{Cu}_{150}$ (AOB4, A4B4), we did not reveal changes in the carotenoid content, but the use of adapted populations led to an increase in the content of chlorophylls.

The results of the analysis of other studied plant parameters showed that inoculation of plants with the control fungus population led to an increase in the content of nitrates in the leaves in variants of substrates with $\mathrm{Cu}_{50}$ and $\mathrm{Cu}_{100}$ ( $\mathrm{AOB} 2$ and $\mathrm{AOB} 3$ ), as well as to an increase in the percentage of dry matter in the root system of plants in variants with $\mathrm{Cu}_{100}$ (AOB3) and $\mathrm{Cu}_{150}$ (AOB4). The use of adapted fungal populations in the cultivation of inoculated plants on a control

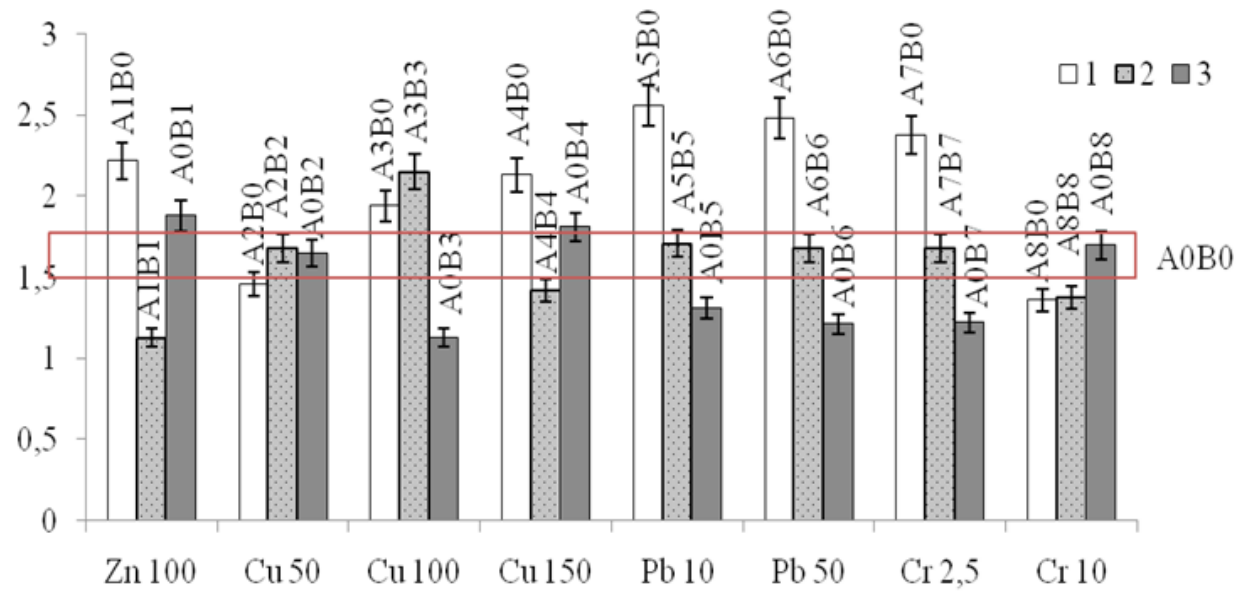

Figure 1. The content of chlorophyll $a$ in the leaves of inoculated tomato plants under conditions of different concentrations of heavy metals in the substrate: 1 - fungus population $\left(\mathrm{A} 1-\mathrm{Zn}_{100} ; \mathrm{A} 2-\mathrm{Cu}_{50} ; \mathrm{A} 3-\mathrm{Cu}_{100} ; \mathrm{A} 4-\mathrm{Cu}_{150} ; \mathrm{A} 5-\mathrm{Pb} \mathrm{b}_{10} ; \mathrm{A6}-\mathrm{Pb} \mathrm{b}_{50} ; \mathrm{A} 7-\mathrm{Cr}_{2,5} ;\right.$ $\left.\mathrm{A} 8-\mathrm{Cr}_{10}\right)+$ substrate without heavy metals (B0); 2 - fungus population $\left(\mathrm{A} 1-\mathrm{Zn}_{100} ; \mathrm{A} 2-\mathrm{Cu}_{50} ; \mathrm{A} 3-\mathrm{Cu}_{100} ; \mathrm{A} 4-\mathrm{Cu}_{150} ; \mathrm{A} 5-\mathrm{Pb}_{10} ;\right.$ $\left.\mathrm{A} 6-\mathrm{Pb}_{50} ; \mathrm{A} 7-\mathrm{Cr}_{2,5} ; \mathrm{A} 8-\mathrm{Cr}_{10}\right)+$ substrate with heavy metals, $\mathrm{mg} \mathrm{l} \mathrm{l}^{-1}\left(\mathrm{~B} 1-\mathrm{Zn}_{100} ; \mathrm{B} 2-\mathrm{Cu}_{50} ; \mathrm{B} 3-\mathrm{Cu}_{100} ; \mathrm{B} 4-\mathrm{Cu}_{150} ; \mathrm{B} 5-\mathrm{Pb}{ }_{10} ; \mathrm{B} 6-\right.$ $\left.\mathrm{Pb}_{50} ; \mathrm{B} 7-\mathrm{Cr}_{2,5} ; \mathrm{B} 8-\mathrm{Cr}_{10}\right) ; 3$ - control population fungi $(\mathrm{A} 0)+$ substrate with heavy metals $\left(\mathrm{B} 1-\mathrm{Zn}_{100} ; \mathrm{B} 2-\mathrm{Cu}_{50} ; \mathrm{B} 3-\mathrm{Cu}_{100} ; \mathrm{B} 4\right.$ $\left.-\mathrm{Cu}_{150} ; \mathrm{B} 5-\mathrm{Pb}_{10} ; \mathrm{B} 6-\mathrm{Pb}_{50} ; \mathrm{B} 7-\mathrm{Cr}_{2,5} ; \mathrm{B} 8-\mathrm{Cr}_{10}\right) ; \mathrm{A} 0 \mathrm{BO}-$ control population of the fungus on the substrate without heavy metals (a rectangle denotes the confidence interval of the average values of the indicator for this option). On the $Y$-axis - content of chlorophyll $a, \mathrm{mg} \mathrm{g}^{-1 "}$; on the $\mathrm{X}$ - axis - content of heavy metals in the substrate, $\mathrm{mg} \mathrm{l}^{-1 \prime \prime}$ 


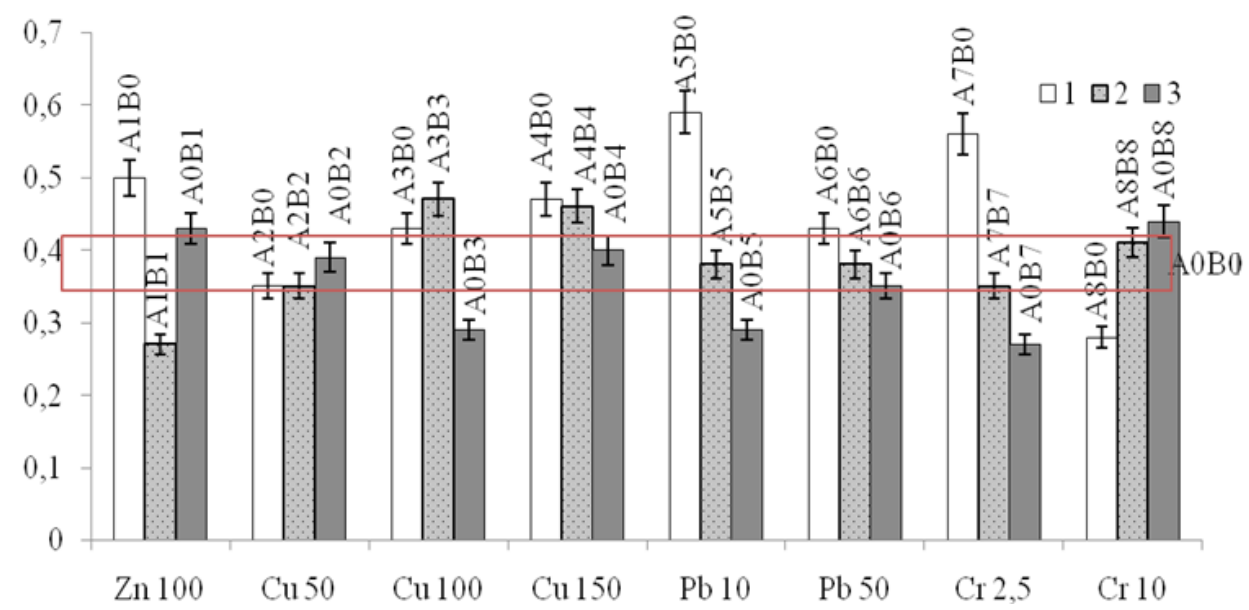

Figure 2. The content of chlorophyll $b$ in the leaves of inoculated tomato plants under conditions of different concentrations of heavy metals in the substrate: 1 - fungus population $\left(\mathrm{A} 1-\mathrm{Zn}_{100} ; \mathrm{A} 2-\mathrm{Cu}_{50} ; \mathrm{A} 3-\mathrm{Cu}_{100} ; \mathrm{A} 4-\mathrm{Cu}_{150} ; \mathrm{A} 5-\mathrm{Pb}{ }_{10} ; \mathrm{A} 6-\mathrm{Pb} \mathrm{b}_{50} ; \mathrm{A} 7-\mathrm{Cr}_{2,5}\right.$; $\left.\mathrm{A} 8-\mathrm{Cr}_{10}\right)+$ substrate without heavy metals (B0); 2 - fungus population $\left(\mathrm{A} 1-\mathrm{Zn}_{100} ; \mathrm{A} 2-\mathrm{Cu}_{50} ; \mathrm{A} 3-\mathrm{Cu}_{100} ; \mathrm{A} 4-\mathrm{Cu}_{150} ; \mathrm{A} 5-\mathrm{Pb}_{10} ;\right.$ $\left.\mathrm{A} 6-\mathrm{Pb}_{50} ; \mathrm{A} 7-\mathrm{Cr}_{2,5} ; \mathrm{A} 8-\mathrm{Cr}_{10}\right)+$ substrate with heavy metals, $\mathrm{mg} \mathrm{l} \mathrm{I}^{-1}\left(\mathrm{~B} 1-\mathrm{Zn}_{100} ; \mathrm{B} 2-\mathrm{Cu}_{50} ; \mathrm{B} 3-\mathrm{Cu}_{100} ; \mathrm{B} 4-\mathrm{Cu}_{150} ; \mathrm{B} 5-\mathrm{Pb}{ }_{10} ; \mathrm{B} 6-\right.$ $\left.\mathrm{Pb}_{50} ; \mathrm{B} 7-\mathrm{Cr}_{2,5} ; \mathrm{B} 8-\mathrm{Cr}_{10}\right) ; 3$ - control population fungi $(\mathrm{A} 0)+$ substrate with heavy metals $\left(\mathrm{B} 1-\mathrm{Zn}_{100} ; \mathrm{B} 2-\mathrm{Cu}_{50} ; \mathrm{B} 3-\mathrm{Cu}_{100} ; \mathrm{B} 4\right.$ $\left.-\mathrm{Cu}_{150} ; \mathrm{B} 5-\mathrm{Pb}_{10} ; \mathrm{B} 6-\mathrm{Pb}_{50} ; \mathrm{B} 7-\mathrm{Cr}_{2,5} ; \mathrm{B} 8-\mathrm{Cr}_{10}\right) ; \mathrm{A} 0 \mathrm{~B} 0$ - control population of the fungus on the substrate without heavy metals (a rectangle denotes the confidence interval of the average values of the indicator for this option). On the Y-axis - content of chlorophyll $b, \mathrm{mg} \mathrm{g}^{-1 \prime \prime}$; on the X- axis - content of heavy metals in the substrate, $\mathrm{mg} \mathrm{I}^{-1 "}$

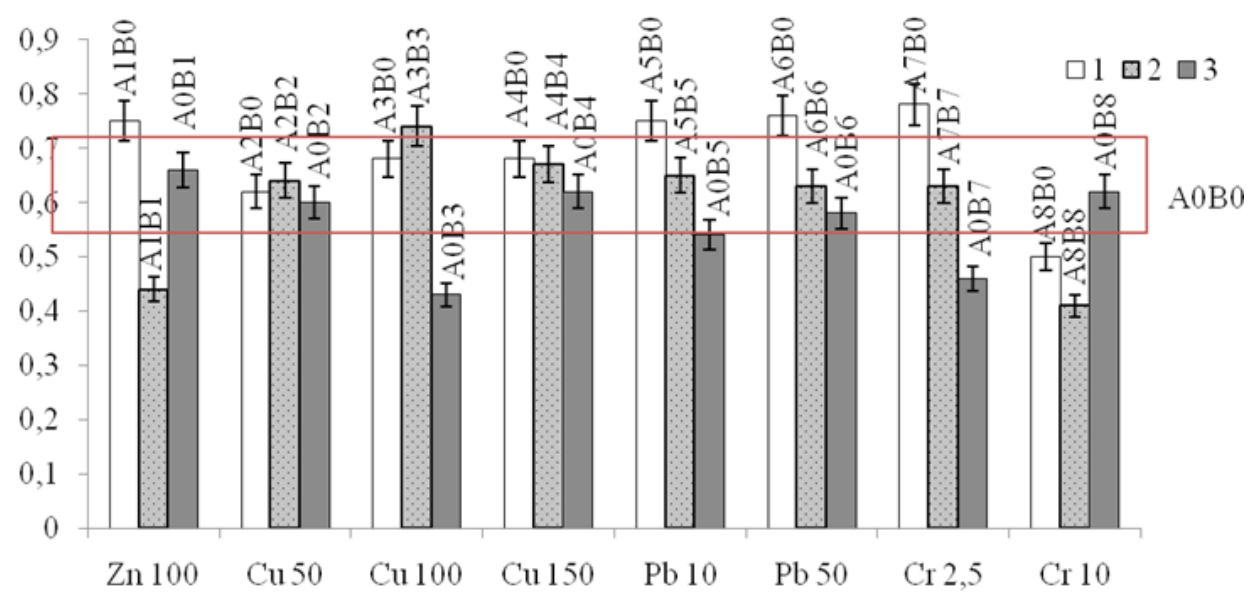

Figure 3. The content of carotenoids in the leaves of inoculated tomato plants under conditions of different concentrations of heavy metals in the substrate: 1 - fungus population $\left(\mathrm{A} 1-\mathrm{Zn}_{100} ; \mathrm{A} 2-\mathrm{Cu}_{50} ; \mathrm{A} 3-\mathrm{Cu}_{100} ; \mathrm{A} 4-\mathrm{Cu}_{150} ; \mathrm{A} 5-\mathrm{Pb} \mathrm{b}_{10} ; \mathrm{A6}-\mathrm{Pb} \mathrm{b}_{50} ; \mathrm{A} 7-\mathrm{Cr}_{2,5} ;\right.$ $\left.A 8-\mathrm{Cr}_{10}\right)+$ substrate without heavy metals (B0); 2 - fungus population $\left(\mathrm{A} 1-\mathrm{Zn}_{100} ; \mathrm{A} 2-\mathrm{Cu}_{50} ; \mathrm{A} 3-\mathrm{Cu}_{100} ; \mathrm{A} 4-\mathrm{Cu}_{150} ; \mathrm{A} 5-\mathrm{Pb}\right.$; $\left.\mathrm{A} 6-\mathrm{Pb}_{50} ; \mathrm{A} 7-\mathrm{Cr}_{2,5} ; \mathrm{A} 8-\mathrm{Cr}_{10}\right)+$ substrate with heavy metals, $\mathrm{mg} \mathrm{l} \mathrm{l}^{-1}\left(\mathrm{~B} 1-\mathrm{Zn}_{100} ; \mathrm{B} 2-\mathrm{Cu}_{50} ; \mathrm{B} 3-\mathrm{Cu}_{100} ; \mathrm{B} 4-\mathrm{Cu}_{150} ; \mathrm{B} 5-\mathrm{Pb}+\mathrm{B} 6-\right.$ $\left.\mathrm{Pb}_{50} ; \mathrm{B} 7-\mathrm{Cr}_{2,5} ; \mathrm{B} 8-\mathrm{Cr}_{10}\right) ; 3$ - control population fungi $(\mathrm{AO})+$ substrate with heavy metals $\left(\mathrm{B} 1-\mathrm{Zn}_{100} ; \mathrm{B} 2-\mathrm{Cu}_{50} ; \mathrm{B} 3-\mathrm{Cu}_{100} ; \mathrm{B} 4\right.$ $\left.-\mathrm{Cu}_{150} ; \mathrm{B} 5-\mathrm{Pb}_{10} ; \mathrm{B} 6-\mathrm{Pb}_{50} ; \mathrm{B} 7-\mathrm{Cr}_{2,5} ; \mathrm{B} 8-\mathrm{Cr}_{10}\right)$; $\mathrm{AOB} 0-$ control population of the fungus on the substrate without heavy metals (a rectangle denotes the confidence interval of the average values of the indicator for this option). On the Y-axis - content of carotenoids, $\mathrm{mg} \mathrm{g}^{-1 "}$; on the X-axis - content of heavy metals in the substrate, $\mathrm{mg} \mathrm{I}^{-1 "}$

substrate (A2-A4B0) led to a decrease in the biomass of the root system and, in variants with $\mathrm{Cu}_{150}(\mathrm{~A} 4 \mathrm{~B} 0)$, to a decrease in the content of nitrates in the leaves. When inoculated with adapted fungal populations on substrates with the addition of $\mathrm{Cu}_{50}$ (A2B2) and $\mathrm{Cu}_{150}$ (A4B4), a significant increase in the content of nitrates in the leaves was noted and, with $\mathrm{Cu}_{100}$ (A3B3), an increase of the top biomass of plants.

The most intensive fungal infection was formed using adapted $\mathrm{Cu}_{100}$ and $\mathrm{Cu}_{150}$ populations, with the maximum development of fungal infection noted in the $\mathrm{Cu}_{100} / \mathrm{Cu}_{100}$ variant (A3B3).
The results of experimental variants using non-biogenic chemical elements (chromium and lead) were of particular interest. When plants were inoculated with the control fungal population and cultured on $\mathrm{Pb}_{10}$ (AOB5) substrate, a true decrease in chlorophyll $a$ and $b$ was observed; on $\mathrm{Pb}_{50}$ (AOB6) substrate, chlorophyll $a$ was observed, while there was no significant decrease in carotenoid content.

The use of adapted fungus populations when growing plants on control substratum (A5-6B0) caused an increase in the content of all studied pigments, but when they were grown on substrates with the addition of lead salts (A5-6B5-6), 
Table 1. Morphological and biochemical parameters of inoculated tomato plants under conditions of different concentrations of heavy metals in the substrate.

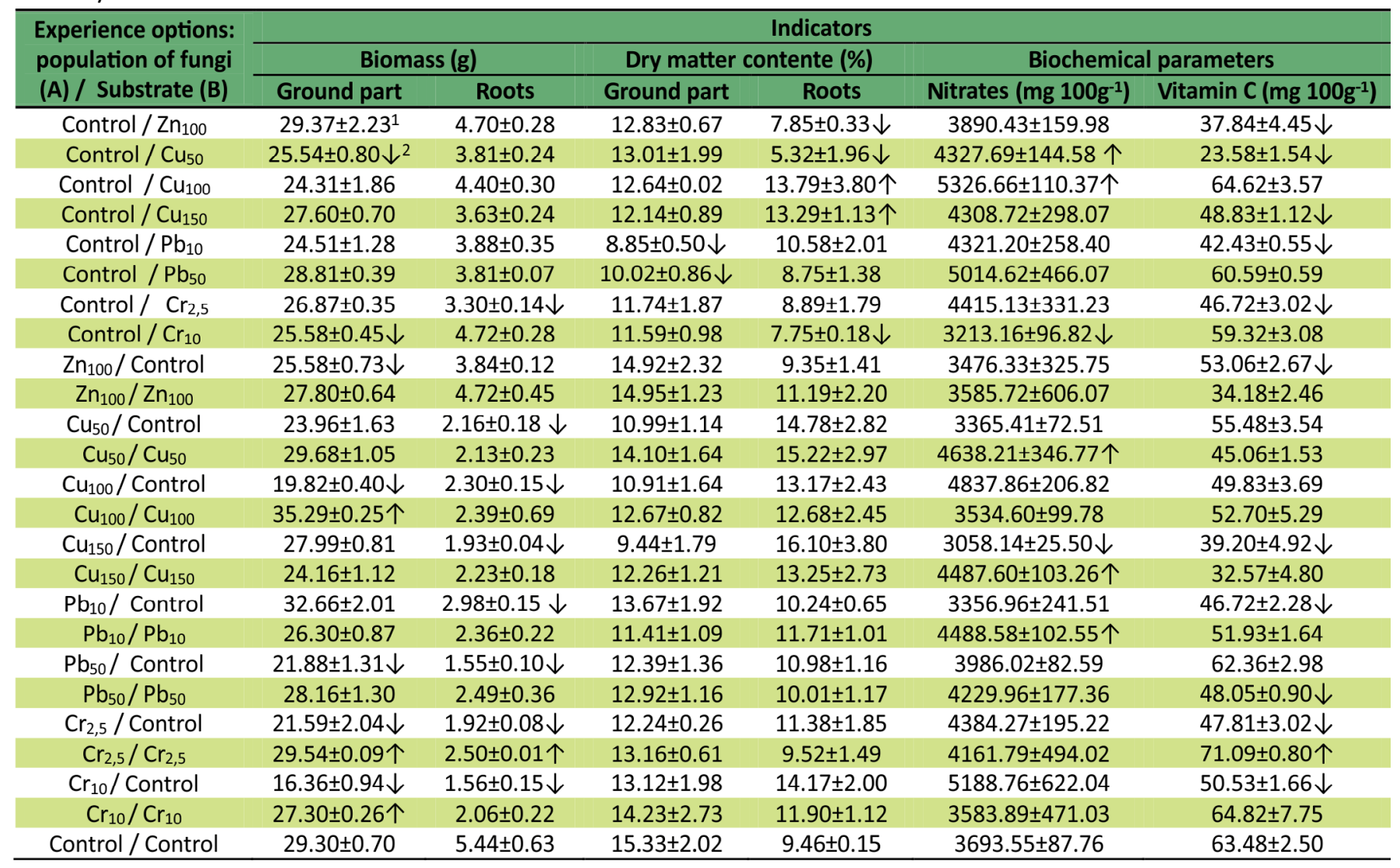

Footnotes. ${ }^{1}$ Here and hereinafter: the average value of the indicator \pm standard deviation; ${ }^{2}$ significant difference from control: increase $\uparrow$ or decrease $\downarrow$ of the indicator ( $<0.05$ ); Control - an initial population that is not adapted to HM (corresponds to AO in Fig. 1-3) and the substrate without metals (corresponds to B0 in Fig. 1-3); A - adapted populations of the fungus grown on agar substrates with the addition of different concentrations of heavy metal salts (mg l-1) (corresponds to A1-A8 in Fig. 1-3); B - substrates with different content of salts of heavy metals ( $\mathrm{mg} \mathrm{l}^{-1}$ ) (corresponds to B1-B8 in Figures 1-3).

no significant changes were revealed in comparison with the control.

The inoculation of plants with the control fungus population led to a significant decrease in the percentage of dry matter in the aerial parts of plants. When using adapted populations and growing plants on a control substratum (A5$6 \mathrm{B0})$, a decrease in the biomass of the root system was noted. Plus, when cultivating plants on substrates with $\mathrm{Pb}_{10}$ (A5B5) and $\mathrm{Pb}_{50}$ (A6B6), the biomass and dry matter content did not have significant changes, but an increase was noted in the content of nitrates in the leaves.

In all variants with lead, the fungal infection in the root system of plants had high development rates - the highest in the variants of Control / $\mathrm{Pb}_{10}, \mathrm{~Pb}_{50}$ (A0B5, A0B6) and $\mathrm{Pb}_{10}, \mathrm{~Pb}_{50}$ / Control (A5B0, A6B0).

In variants with chromium inoculation of plants with a control population, when cultured on a substrate with $\mathrm{Cr}_{2,5}$ (A0B7) this led to a significant decrease in the pigment content in the leaves, but not on a substrate with $\mathrm{Cr}_{10}$ (AOB8).

The inoculation of plants with adapted fungal populations during their cultivation on control substrates had differences: with $\mathrm{Cr}_{2,5}$ it caused a significant increase in the content of photosynthetic pigments (A7B0) and, in contrast, with $\mathrm{Cr}_{10}$ (A8B0) a significant decrease in their content. When cultivating plants on a substrate with the addition of $\mathrm{Cr}_{2,5}$
(A7B7), there were no significant changes observed, and only when $\mathrm{Cr}_{10}$ (A8B8) was added was a decrease in the content of chlorophyll $a$ and carotenoids observed in the absence of significant differences with the control in the content of chlorophyll $b$.

When plants were inoculated with a control fungus population and cultured on a substrate with $\mathrm{Cr}_{10}$ (AOB8), we observed a decrease in the indicators of the top biomass, the percentage of dry matter in the root system of plants, and nitrates in the leaves. The results are of interest in variants using plant inoculation with adapted fungal populations: when cultivating plants on control substrates, we observed a decrease in the biomass of the aerial part and root system of plants, but when plants were cultivated on substrates with chromium, on the contrary, there was an increase in plant biomass.

In variants with chromium, the use of adapted fungus populations led to the highest rates of development of fungal infection in the root of the plants, with the highest rates at the highest chromium content in the substrate $\left(\mathrm{Cr}_{10} / \mathrm{Cr}_{10}\right.$ variant).

As for the content of ascorbic acid (vitamin C) in plant leaves, we found that when plants are inoculated with a control fungus population during their cultivation on substrates with the addition of heavy metal salts then its content decreases. For inoculations with adapted fungus populations during their 
cultivation on a control substrate, there are no significant vitamin $\mathrm{C}$ changes (excluding $\mathrm{Pb}_{50}$ and $\mathrm{Cu}_{150}$, where decreases occur). In the variants of the adapted fungal populations/ substrate with heavy metals, significant differences are found only in the variants $\mathrm{Pb}_{50} / \mathrm{Pb}_{50}$ (decrease) and $\mathrm{Cr}_{2.5} / \mathrm{Cr}_{2.5}$ (increase).

Thus, with regard to the response of plants to various concentrations of biogenic chemical elements in the substrate, the inoculation of $C$. magnusianum plants did not have a positive effect on the plant resistance to high concentrations of zinc salts, but at the same time had a positive effect on the resistance to high concentrations of copper salts. In addition to changing the content of photosynthetic pigments, the inoculation affected the root system of the plants and the nitrate content in the leaves. These results are consistent with the data on the formation of adaptive plant responses upon inoculation with symbiotic micromycetes under chemical stress caused by heavy metal salts. A feature associated with more efficient absorption of nitrogen by inoculated plants should be noted, which is important to take into account for studies aimed at the practical use of inoculation technology in plant cultivation as well as in protected ground conditions.

Chromium and lead are toxic elements for plants. However, in our experiments, it was found that the inoculation of plants and, especially, fungal populations previously adapted to the action of heavy metal salts leads to an increase in plants' metal resistance. In the scientific literature, we did not find C. magnusianum as a partner influencing the resistance of plants to heavy metals. However, there are many publications confirming the role, for example, of arbuscular mycorrhizal fungi in the formation of plant resistance to heavy metals (Seguel et al., 2013; Shabani et al., 2016; Spagnoletti et al., 2016; Sharma et al., 2019). The results of our research, using non-biogenic chemical elements that are hazardous to plant life, are similar. They are coherent with the opinion of the authors of a number of scientific publications about a peculiar form of partnership between endotrophic fungi and the root system of plants: the protective effect of fungi is most effectively manifested under conditions least favorable for plant life (Bilal et al., 2019; Li et al., 2019; Hou et al., 2020).

\section{Conclusions}

The content of chlorophylls $a$ and $b$ is the most sensitive indicator of the plants' state when using the inoculation technique.

Plants' inoculation with a Cylindrocarpon magnusianum culture (control) did not have a significant effect on the formation of adaptive reactions that increase metal resistance in plants;

Upon the inoculation of plants with C. magnusianum populations adapted to the action of heavy metal salts, a positive effect manifested itself in variants for Cu100 and Cu150 when growing plants on a control substrate and on substrates with copper; for Zn100 - only when growing plants on a control substrate.
During the cultivation of plants on substrates with different chromium and lead contents, the adaptive reactions of plants were most significantly manifested during the inoculation of plants with adapted $C$. magnusianum populations

Fungal infection in the root system of plants in all variants of the experiment was well developed, with the maximum found in variants with the highest chromium content.

We observed the maximum effect of the partnership between tomato and $C$. magnusianum under conditions least favorable for the life of plants, which makes the use of plant inoculation very popular, promising, and relevant in the creation of artificial ecosystems, and in the control and regulation of plant resistance in extreme conditions.

\section{Compliance with Ethical Standards}

Funding: The research was supported by a grant from the Russian Fund for Fundamental Research "Graduate Student" No. 19-316-90003.

Conflict of interest: The authors declare that they have no conflicts and competing interests.

Author contributions: Conceptualization: IB; Data curation: IB; Formal analysis: NI; Funding acquisition: IB; Investigation: IB; Methodology: NI; Project administration: IB; Resources: IB; Supervision: IB; Validation: NI; Visualization: NI; Writing - original draft: NI; Writing - review \& editing: IB.

\section{Literature Cited}

Ali, A.; Bilal, S.; Khan, A. L.; Mabood, F.; Al-Harrasi, A.; Lee, I.-J. Endophytic Aureobasidium pullulans BSS6 assisted developments in phytoremediation potentials of Cucumis sativus under $\mathrm{Cd}$ and $\mathrm{Pb}$ stress. Journal of Plant Interactions, v.14, n.1, p.303-313, 2019. https://doi.org/10.1080/17429145.2019.1633428.

Amaral, D. R.; Oliveira, D. F.; Campos, V. P.; De Carvalho, D. A.; Nunes, A. S. Effect of plant and fungous metabolites on Meloidogyne exigua. Ciência e Agrotecnologia, v.33, p.1861-1865, 2009. https://doi.org/10.1590/S1413-70542009000700027.

Bilal, S.; Shahzad, R.; Imran, M.; Jan, R.; Min, K.; Lee, I.-J. Synergistic association of endophytic fungi enhances Glycine max $\mathrm{L}$. resilience to combined abiotic stresses: Heavy metals, high temperature and drought stress. Industrial Crops \& Products, v.143, e111931, 2020. https://doi.org/10.1016/j.indcrop.2019.111931.

Bilal, S.; Shahzad, R.; Khan, A. L.; Al-Harrasi, A.; Kim, C. K.; Lee, I.J. Phytohormones enabled endophytic Penicillium funiculosum LHL06 protects Glycine max L. from synergistic toxicity of heavy metals by hormonal and stress-responsive proteins modulation. Journal of Hazardous Materials, v.379, e120824, 2019. https:// doi.org/10.1016/j.jhazmat.2019.120824.

Boyette, C. D.; Hoagland, R. E.; Stetina, K. C. Efficacy improvement of a bioherbicidal fungus using a formulation-based approach. American Journal of Plant Sciences, v.7, n.16, p.2349-2358, 2016. https://doi.org/10.4236/ajps.2016.716206.

Boyette, C. D.; Hoagland, R. E.; Stetina, K. C. Hot water treatment enhances the bioherbicidal efficacy of a fungus. American Journal of Plant Sciences, v.9, n.10, p.2063-2076, 2018. https:// doi.org/10.4236/ajps.2018.910150. 
Bukharina, I.; Franken, P.; Kamasheva, A.; Vedernikov, K.; Islamova, N. About the species composition of microscopic fungi in soils and woody plant roots in urban environment. International Journal of Advanced Biotechnology and Research, v.7, n.4, p.1387-1394, 2016. http://www.bipublication.com/ijabr74.html. 02 Aug. 2020.

Bukharina, I.L.; Islamova, N.A. Study of the stability limits of microscopic fungi and the formation of a collection of promising isolates. In: Annual Meeting of the Society of Plant Physiologists of Russia, 2016, St Petersburg. Proceedings... 2016. St Petersburg: Publishing House of St Petersburg University, 2016. p.362-363.

Dabral, S.; Varma, A.; Choudhary, D. K.; Bahuguna, R. N.; Nath, M. Biopriming with Piriformospora indica ameliorates cadmium stress in rice by lowering oxidative stress and cell death in root cells. Ecotoxicology and Environmental Safety, v.186, e109741, 2019. https://doi.org/10.1016/j.ecoenv.2019.109741.

El-Samad, H. M.; El-Hakeem, K. N. S. Strategy role of mycorrhiza inoculation on osmotic pressure, chemical constituents, and growth yield of maize plant gown under drought stress. American Journal of Plant Sciences, v.10, n.6, p.1102-1120, 2019. https:// doi.org/10.4236/ajps.2019.106080.

Gostperevod. GOST 29270-95. Fruits and vegetables products. Methods for the determination of nitrates. Moscow: Standartinform, 2010. https://gostperevod.com/gost-29270-95.html. 28 Jul. 2020.

Gostperevod. GOST 28561-90. Fruit and vegetable products. Methods for determination of total solids or moisture. Moscow: Standartinform, 2011. https://gostperevod.com/gost-28561-90. html. 28 Jul. 2020.

Hou, L.; Yu, J.; Zhao, L.; He, X. Dark septate endophytes improve the growth and the tolerance of Medicago sativa and Ammopiptanthus mongolicus under cadmium stress. Frontiers in Microbiology, v.10, e 3061, 2020. https://doi.org/10.3389/fmicb.2019.03061.

Ijdo, M.; Cranenbrouck, S.; Declerck, S. Methods for large-scale production of AM fungi: past, present and future. Mycorrhiza, v.21, p.1-16, 2011. https://doi.org/10.1007/s00572-010-0337-z.

Ikram, M.; Ali, I. N.; Jan, G.; Jan, F. G.; Rahman, I. U.; Iqball, A.; Hamayu, M. IAA producing fungal endophyte Penicillium roqueforti Thom., enhances stress tolerance and nutrients uptake in wheat plants grown on heavy metal contaminated soils. PLoS One, v.13, n.11, e0208150, 2018. https://doi.org/10.1371/journal.pone.0208150.

Li, X.; Zhang, X.; Wang, X.; Yang, X.; Cui, Z. Bioaugmentation-assisted phytoremediation of lead and salinity co-contaminated soil by Suaeda salsa and Trichoderma asperellum. Chemosphere, v.224, p.716-725, 2019. https://doi.org/10.1016/j.chemosphere.2019.02.184.
Meepagala, K. M.; Clausen, B. M.; Johnson, R. D.; Wedge, D. E.; Duke, S. O. A phytotoxic and antifungal metabolite (Pyrichalasin $\mathrm{H}$ ) from a fungus infecting Brachiaria eruciformis (Signal Grass). Journal of Agricultural Chemistry and Environment, v.8, n.3, p.115-128, 2019. https://doi.org/10.4236/jacen.2019.83010.

Rodriguez, R. J.; White, J. F.; Arnold, A. E.; Redman, R. S. Fungal endophytes: diversity and functional roles. New Phytologist, v.182, p.314-330, 2009. https://doi.org/10.1111/j.14698137.2009.02773.x.

Seguel, A.; Cumming, J. R.; Klugh-Stewart, K.; Cornejo, P.; Borie, F. The role of arbuscular mycorrhizas in decreasing aluminium phytotoxicity in acidic soils: A review. Mycorrhiza, v.23, p.167183, 2013. https://doi.org/10.1007/s00572-013-0479-x.

Shabani, L.; Sabzalian, M. R.; Mostafavi, S. Arbuscular mycorrhiza affects nickel translocation and expression of $A B C$ transporter and metallothionein genes in Festuca arundinacea. Mycorrhiza, v.26, p.67-76, 2016. https://doi.org/10.1007/s00572-015-06472.

Sharma, V. K.; Li, X.; Wu, G.; Bai, W.; Parmar, S.; White Jr., J. F.; Li, H. Endophytic community of $\mathrm{Pb}-\mathrm{Zn}$ hyperaccumulator Arabis alpina and its role in host plants metal tolerance. Plant Soil, v.437, p.397-411, 2019. https://doi.org/10.1007/s11104-019-03988-0.

Shtark, O. Yu.; Labutova, N. M. Traditional methods of working with arbuscular mycorrhizal fungi. SPb: GNU VNIISCHM, 2014. 44p.

Sobowale, A. A. Probable effects of dual inoculation of maize (Zea mays) stem with Fusarium verticillioides and certain Trichoderma species on fumonisin content of maize seeds. American Journal of Plant Sciences, v.10, n.5, p.752-759, 2019. https://doi. org/10.4236/ajps.2019.105055.

Sogonov, M. V.; Velikanov, L. L. Soilmicrofungi from alpine and subnival ecosystems of the Northwestern Caucasus. Mikologiya I Fitopatologiya (in Russian), v.38, n.3, p.50-58, 2004.

Spagnoletti, F. N.; Balestrasse, K.; Lavado, R. S.; Giacometti, R. Arbuscular mycorrhiza detoxifying response against arsenic and pathogenic fungus in soybean. Ecotoxicology and Environmental Safety, v.133, p.47-56, 2016. https://doi.org/10.1016/j. ecoenv.2016.06.012.

Yurkov, A. P.; Kryukov, A. A.; Gorbunova, A. O.; Kozhemyakov, A. P.; Stepanova, G. V.; Machs, E. M.; Radionov, A. V.; Shishova, M. F. Molecular genetic identification of arbuscular mycorrhiza fungi. Ecological Genetics, v.16, n.2, p.11-23, 2018. https://doi. org/10.17816/ecogen16211-23. 